\title{
Una teología más simbólica y popular*
}

\author{
VICTOR CODINA \\ Centro de Investigación y \\ Servicio Popular, \\ Oruro, Bolivia.
}

1. Punto de partida: la opción por los pobres

Desde hace algunos años, la teología se ha vuelto a interesar por el símbolo desde diversos ángulos. Teólogos sistemáticos, como K. Rahner en el campo católico y $P$. Tillich en el protestante, han revalorizado la importancia del aímbolo para una visión global de la teología. Para Rahner, todo ente es simbolico, ya que necesariamente se expresa para hallar su propio ser; el símbolo ea autorrealización de un ente en otro y constituye un concepto esencial en todos los tratados teológicos, de la trinidad a la escatología; y el modo de obrar Dios en la historia de salvación, desde el origen a su plenitud, es simbólico. ${ }^{1}$ Para Tillich el símbolo se caracteriza por su relacionalidad y su pregnancia: en él transparece lo incondicionado. La teología litúrgica y sacramental es la que ha desarrollado más la dimensión simbólica, recuperando así la rica tradición patrística: 0. Casel, A. Vonier, J. Daniélou, O. Semmelroth, E. Schillebexck, C. Vagagini, I. Onatibia,L. M. Chauvet,L. Boff... A esta recuperación ha colaborado positivamente el diálogo con las ciencias humanas, el cual también ha redescubierto el símbolo desde la psicología profunda (Freud, Jung, Bachelard, Durand..), desde la antropologia (Durkheim, Levy Bruhi, Saussure, LéviStrauss, Cassirer, Ricoeur...). También la historia de las religiones (Mircea Elíade, Van den Leuwen...) y el contacto con autores del mundo orientul cristiano (vg.P. Evdokimov, 0. Clément, A. Schememann) y del mundo del oriente no cristiano, han

\footnotetext{
- Este artículo serí publicado en portugués en Perspectiva Teologiea, Brasil.
} 
contribuido positivamente a este redescubrimiento del símbolo en la teología ca tólica.

La teología moderna reconoce que el símbolo es el único modo de acceder a las realidades más profundas y de llegar a la tolalidad de la persona. Se intenta con esta recuperación del símbolo superar el intelectualismo racionalista, el idealismo y el cientismo positivista, típico de otros momentos históricos.

Nuegtro punto de partida pretende dar un paso más allá de la modernidad. Desearíamos potenciar lo simbólico desde la opción preferencial por los pobres de la Iglesia de hoy, concretamente de la Iglesia de América Latina (Puebla, 1134-1165).

Eata tarea es urgente, sobre todo en América Latina, para no agravar más el divorcio entre la Iglesia oficial y el pueblo. Mientras las expresiones oficiales de la Iglesia en su magisterio, teología, moral, espiritual e incluso liturgia, adolecen de un marcado intelectualismo (fomentado en los centros de formación teológica), el pueblo vive una religiosidad marcadamente simbólica en su fe, en sus devociones y en su espiritualidad. En la descripción que Puebla nos ofrece de la religiosidad po. pular latinoamericana se advierte una fuerte connotación simbólica: "Como elementos posıtivos de la piedad popular se pueden señalar: la presencia trinitaria que se percibe en devociones y en iconografías, el sentido de la providencia de Dios Padre; Cristo, celebrado en su misterio de Encarnación (Navidad, el Niño), en su crucifixión, en la Eucaristía y en la devoción al Sagrado Corazón; amor a María: ella y 'sus misterios pertenecen a la identidad propia de estos pueblos y caracterizan su piedad popular' (Juan Pablo II), venerada como Madre Inmaculada de Dios y de los hombres, como Reina de nuestros distintos países y del continente entero; los santos, como protectores; los difuntos; la conciencia de dignidad personal y de fraternidad solidaria; la conciencia de pecado y la necesidad de expiación; la capacidad de expresar la fe en un lenguaje total que supera los racionalismos (canto, imágenes, gesto, color, danza); la Fe situada en el tiempo (fiestas) y en lugares (santuarios y templos); la sensibilidad hacia la peregrinación como símbolo de la existencia humana y cristiana, el respeto filial a los pastores como representantes de Dios; la capacidad de celebrar la fe de Corma expresiva y comunitaria; la integración honda de los sacramentos y sacramentales en la vida personal y social; el efecto cálido por la peroona del Santo Padre; la capacidad de sufrimiento y heroísmo para sobrellevar pruebes y confeser la fe; el valor de la oración, la aceptación de los demás" (Puebla, 454).

El pueblo alcanza a través del símbolo un asentamiento real y no meramente nocional de la fe, para usar categorías de Newman.

La recuperación de lo simbólico es totalmente necesaria para cvangelizar al pueblo y su religiosidad. Y también es verdad que el pueblo, al mantener lo simbólico más fuertemente que otros seclores eclesiales, evangeliza a la misma teología moderna. Una vez más se realiza el potencial evangelizador de los pobres (Puebla, 1147).

Pero estudiar lo simbólico desde la perspectiva popular va más allá de una pre. ocupación pastoral y de alguna forma filosófico formal sobre la connaturalidad del pueblo con el símbolo. Como iremos viendo a lo largo de estas páginas, el pobre es en sí mismo un símbolo teológico privilegiado del Señor (Puebla, 196; 31-39). El método y el contenido son inseparables. No es casual que la pérdida de lo sinbólico en 
la teología coincida con el alejamiento del pueblo de la Iglesia oficial. Ś́lo una teología simbólica podrá hacer del pobre un lugar teológico privilegiado.

Esta tentativa de recuperar lo simbólico es, por otra parte, típica del "talante católico" (P. Tillich), y deberá siempre completarse con las dimensiones proféticas y ulópicas de la fe, para que lo simbólico no se convierta en "diabólico" (L. Boff).

Sólo una connaturalidad con el pueblo, con su clamor y su historia de pasión, podrá proporcionarnos el contexto humano y cristiano necesario para esta búsqueda del símbolo, para no caer de nuevo en esteticismos etilistas, ni en sutiles formas de racionalismo bajo capa de simbolismo.

En un encuentro de comunidades eclesiales de base, una mujer minera, en la eucaristía, ofreció una olla vacía, como símbolo de su pobreza y del hambre del pueblo. ¿Acaso esta olla vacía no dice más que muchos discursos sobre "los gozos y esperanzas, las tristezas y angustias de los hombres de nuestro tiempo, sobre todo de los pobres y de los que sufren" (GS l).

\section{Aproximación al símbolo}

Es difícil definir el símbolo, ya que por su misma esencia el símbolo rompe los esquemas meramente conceptuales. El símbolo no obedece a las leyes de la lógica, sino a las de la imagen. Tan sólo se le puede describir, como cuando los niños responden a preguntas abstractas con respuestas concretas: símbolo es comer juntos, danzar, abrazarse, ofrecer flores, celebrar una fiesta, arrodillarse ante una imagen, derribar la estatua del dictador, quemar la bandera de la metrópoli colonial, peregrinar a un santuario, celebrar la eucaristía...

El hombre es un ser simbólico por su propia naturaleza. El pensamiento simbólico no es algo puramente primitivo, infantil o prelógico, sino una estructura fundamental de la comprensión y de la comunicación humana, que aunque pueda y deba ser completada con otros tipos de pensamiento (lógico, científico...) es insustituible, sobre todo en el ámbito religioso. El misterio sólo se puede expresar de forma simbólica.

El símbolo es, pues, la única forma de expresar las realidades más profundas de la existencia humana, de comunicarlas socialmente y de entrar en comunión con ellas. Esto vale para el arte, la psicología, la cultura, la política, la historia y la religión. El símbolo religioso, del que nos ocupamos ahora, no es una excepción a todo el mundo simbólico, sino una concreción y profundización del universo simbólico. El símbolo, al mismo tiempo que expresa el misterio, mantiene el hialo entre el misterio y el modo de expresarlo.

En el símbolo se explicita lo implícito, lo cual no es una mera exteriorización de algo ya preexistente, sino que el sólo hecho de manifestar lo oculto crea una nueva presencia. Así, el abrazo conyugal expresa el amor mutuo y la entrega, la significa, la intensifica, la eterniza en la nueva realidad del hijo.

El símbolo remite a algo misterioso y prolundo, está grávido de una realidad mayor que él mismo, la cual a través del símbolo se vuelve transparente, sin lograr nunca agotarla. El símbolo transfigura la realidad, la hace más profunda, nos hace 
participar de su misterio último. Cuando esta dimensión es la profundidad última, el símbolo es religioso.

Toda comida expresa y actualiza los vínculos de comunión de los comensales, compañeros que comen en común del mismo pan. La comida ritual nos hace entrar en comunión con Dios, fundamento último de nuestra vida y de nuestra comunidad.

En el símbolo se condensan una serie de significados y de sentidos inagotables que son imposibles de captar en el pensamiento meramente lógico o científico. Siempre hay un residuo supra-racional, una plusvalía de sentido, que no puede ser apresado por los conceptos meramente racionales. Esto explica la potencialidad de sentido del símbolo, su polisemie, au riqueza semántica, su polivalencia analógice. La fiesta es un buen ejemplo de esta pluralidad de significados: la comida, el culto, la danza, el canto, la riqueza ornamental y artística, el escenario, la exuberancia, el exceso, la imaginación, la crítica, el humor... de la fiesta popular, no son fácilmente racionalizables en un enunciado meramente lógico o en una fórmula matemática, eino que forman como una constelación simbólica, un sistema polisémico de sentidos y valores profundos.

El símbolo se realiza, de ordinario, a través del mito y del rito. El mito es un símbolo distendido en forma de relato, situado en un tiempo y un espacio no conmesurables con el tiempo y el espacio geográfico. Es inútil buscar el paraíso terrenal entre los ríos Pisón, Guijón, Tigris, y Eúfrates (Gn. 2,10-14). El rito es la plaamación gestual del mito, su dramatización y actualización festiva.

Entre el mito y el rito discurre la existencia humana, su drama y su angustia. De esta forma el símbolo como algo no puramente estático, sino como una accí́n(actio), una praxis, una forma de vivir la vida, liberándola de todo lo inauténtico y opresor, y penetrado en su núcleo más profundo.

En esta acción simbólica intercambiamos con los demás y nos aglutinamos co. mo comunidad histórica con sentido. Etimológicamente el symbolon es un objeto partido, del cual cada participante guarda un fragmento, que luego al juntarse de nuevo, permite el reconocimiento de la antigua amistad. Asf, los antiguos comensales, al juntar de nuevo los trozos del plato o copas rotas, se reconocen como miembros del grupo. El símbolo es un mediador de comunión y de identidad. Así, el Símbolo de los apóstoles o Credo, permitía a los primeros cristianos identificarse como miembros de una misma fe en una misma Iglesia.

El símbolo, en sentido estricto, se diferencia del mero signo. El signo remite a algo exterior a él mismo, no tiene relación intrínseca con el significado y puede por tanto ser elegido arbitrariamente. La nomenclatura de los elementos químicos ea to. talmente libre y no contiene lo que ellos significan. Sirve para designar, apela simplemente al conocimiento racional. El signo Au significa oro, pero él mismo no es oro. Nadie sacia su sed con la fórmula $\mathrm{H}_{2} \mathrm{O}$...

En el símbolo, por el contrario, se da una presencia de lo simbolizado, nos introduce en un orden diferente y superior del cual el mismo símbolo forma parte. Más que designar cosas, transparenta y comunica la trascendencia en la inmanencia.

El signo tiene una perspectiva instrumentalizada, sirve para, no tiene sentido en sí mismo, sino en función de otra realidad. El símbolo no sirve para algo ajeno a 
sl mismo, sino que tiene sentido en sí y por sí mismo. Es "intransitivo," no significa aada, es lo que simboliza; y lo simbolizado sólo se puede dar en el símbolo. Por esto el símbolo resiste a ser tratado discursivamente. El símbolo existe en el acto mismo de su expresión y de su comunicación. Es un acontecimiento gratuito e indomesticable. Cuando Ghandi quemó los tejidos ingleses en la India, estaba expresando el rechazo de la colonia y el ansia de libertad del pueblo y de algún modo estaba iniciando su liberación. Cuando el pueblo ofrece una velita a la Virgen, expresa simbólicamente su amor y au devoción a María. Cuando el pueblo por navidad se acerca a adorar y besar al Niño de Belén, no besa a un trozo de yeso, sino que agradece a Jesús au venida a este mundo. Cuando Jesús lava los pies a sus diacípulos, no realiza un aimple gesto de purificación ritual, sino que simboliza toda su vida de entrega y de aervicio humilde a la humanidad: habiendo amado a los suyos, los amó hasta el extremo (Jn. 13,1).

Una teología simbólica es le que parte de los símbolos (cósmicos, humanos, históricos), es la que los interpreta, la que utiliza un lenguaje simbólico y se ordena a una praxis simbólica del seguimiento de Jesúe. Es una teología que capta la revelación de Dios a través de los símbolos de la naturaleza y de la historia, y sobre todo de Jesús, imagen del Dios Invisible (Col. 1,15), misteriosamente presente en los pobres y pequeños (Mt. 25, 31-45; Lc. 10,16; Mt. 10,40; Hech. 9.5), que constituyen símbolos especiales del Señor. Es una teología que está al servicio de la Iglesia, ella misma símbolo del reino; es una teología que se comunica a través de los diferentes símbolos de la fe, de los sacramentos y de todas las mediaciones simbólicas. Es una leología que no se limita a comunicar un mensaje nocional, sino que pretende iniciar una vida nueva, de la cual comenzamos a participar simbólicamente. Es una teología que intenta expresar la salvación de Dios, misterio de fe, a través de los símbolos adecuados a cada momento histórico. Hoy la liberación es la expresión simbólica de la salvación. Es una teología bíblica, narrativa, cósmica, celebrativa, lilúrgice, imaginativa, poética, icónica, profética, utópica, comunitaria, popular y liberadora. Y también es una teología más atenta a la realidad femenina, ya que la mujer posee una especial connaturalidad con el símbolo.

\section{Evolución histórica}

\section{La Escritura}

Tanto el Antiguo como el Nuevo Testamento poseen un profundo carácter sim. bólico. Dios se comunica al mundo a través de símbolos, revelándose a través de palabras y hechos simb6licos (DV 2). Esta revelación alcanza su plenitud en Jesús (Hb. 1,1-2; DV 4), quien es la imagen del Dios que no se puede ver (Col. 1,15), el símbolo del Padre, de tal forma que viéndole a El, conocemos al Padre (Jn. 14,9).

Por otra parte, al ser la Biblia el libro del pueblo de Dios, pueblo pobre y sencillo, y por connaturalidad simbólico, es coherente que su contenido también tenga lenguaje simbólico. Concretemos esta afirmación con algunos ejemplos bíblicos, tanto de relatos como de acciones simbólicas.

Los relatos de los orígenes constituyen un ejemplo claro de lenguaje simbólico. El género literario llamado etiológico expresa simbólicamente una profunda reflexión sobre la génesis de una historia. Los 11 primeros capítulos del Génesis constitu. 
yen el ejemplo más conocido. Pero el génesis etiológico y su carácter simbólico se extiende también al Nuevo Testamento. Las narraciones de la infancia de Jesús (Lc. 1.2; Mt. 1-2) expresan de forma simbólica el misterio de Jesús y anticipan a la luz de la pascua, su vida y su destino futuro. El nacimiento de la Iglesia está descrito de forma simbólica. En la elección de los apóstoles (Mc. 3,13-19 y paralelos), el número 12 simboliza las 12 tribus de Israel. Las narraciones sobre el primado de Pedro (Mt. 16,13-20; Jn. 21), son narraciones cargadas de simbología: piedra, puertas del infierno, llaves, atar y desatar, pesca, comida con panes y pescados, apacentar corderos y ovejas... La institución de la eucaristía (Mt. 26, 17; Mc. 14, 19; Lc. 22, 17; 1 Cor. $11,23 . .$.$) es por su misma esencia ritual, un relato simbólico: cena pascual de despe-$ dida, pan y vino compartido que simboliza la entrega sacrificial de Jesús a su muerte y anticipa el banquete del reino. El relato de pentecostés está cargado de símbolos: viento, ruido, lenguas de fuego, hablar en diferentes idiomas, una comunidad que crece unida en la doctrina apostólica, en la fracción del pan y en la solidari. dad económica. Las apariciones del resucitado, el comienzo del mundo nuevo de la escatología, revisten también carácler simbólico. Es innecesario repetir que esta dimensión simbólica no sólo no se opone a la realidad, sino que es la única forma de expresar la verdad trascedente del misterio de fe que se nos manifiesta en nuestra historia concreta.

Si los orígenes han de ser expresados de forma simbólica, también la anticipación de la utopía escatológica sólo puede ser descrita a través de símbolos: "harán arados de sus espadas y sacarán hoces de sus lanzas" (Is. 2,4), "el lobo habitará con el cordero" (Is. 11,6), habrá "un cielo nuevo y una tierra nueva" (Is. 65,17), donde no habrá sollozos ni tristeza, ni gritos de angustia (Is. 65.19), sino un banquete de carnes sabrosas y vinos abundantes $(0$ s. 25,6$)$. Todo el género apocalíptico es esencialmente simbólico y se engañaría el que interpretara de forma puramente geográfica la ausencia del mar en la nuevą Jerusalén (Apoc. 21,ī). Los símbolos se encabalgan: nuevo cielo y nueva tierra, ciudad santa, novia engalanada, paraíso con un río de agua brillante como el cristal y con árboles de vida (Apoc. 21-22).

También en los evangelios el misterio del reino de Dios es descrito simbólicamente a través de parábolas (Mt. 13) y de gestos simbólicos de Jesús (Lc. 7, 18-23; $11,20)$.

Acciones simbólicas jalonan tanto el Antiguo como el Nuevo Testamento. La liturgia penitencial en Joel 1,5-14 o la dramática exclusión del incestuoso de Corinto (1Cor. 5) pueden ser ejemplos claros. En particular merecen destacarse los gestos proféticos que en su misma realización anticipan el futuro, realizan lo que signifi. can y orientan la historia hacia el reino escatológico de Dios. Eslos gestos simbóli$\cos (o t)$ presuponen un ambiente denso e importante que hace necesario una expresión no meramente verbal. Estas acciones proféticas se hallan en los antiguos profetas como Samuel (1Sam. 15, 17-28), Ajías (1Re. 11, 29-33) y en los profetas clásicos. Así, Ezequiel dramatiza simbólicamente la suerte del pueblo a través de la mímica del deportado (Ez. 12, 1.20), la comida racionada (Ez. 4, 9-17); la dispersión de los cabellog (Ez. 4-5). Jeremías también ejecuta geslos simbólicos: la vara del almendro y la olle (Jer. 1, 11-14), la faja escondida en el Eúfrates (Jer. 13, 1-11), el alfarero (Jer. 18,1-12), el jarro roto (Jer. 19), elc. Sus mismas vidas constituyen, a veces símbolos 
vivos para el pueblo (0s. 1-3; 1s. 20; 7,3; 8,1-4 8,18; Ez. 4,4-8; 24, 15-24; 25,15-27; 33,22; Jer. 16,1-4;36,5; 15,17).

También en los evangelios nos encontramos con gestos proféticos de Jesús de carácter simbólico: comer con los pescadores (Lc. 15,1) es señal de que el reino de Dios invierte la jerarquía de valores habituales en el mundo farisaico. Los milagros de Jesús son señales de que el reino de Dios se ha acercado en Jesús y precisamente a los pobres de este mundo (Lc. 4, 16-22). El llanto de Jesús sobre Jerusalén (19,41) y la maldición de la higuera (Mt. 21,28; Lc. 13,6; Mc. 11,12.14) simbolizan el triste futuro de Israel por su infidelidad. El lavatorio de los pies significa la vida de amor y servicio humilde de Jesús (Jn. 13). La última cena es también una acción profética, una parábola en acción que simboliza su entrega sacrificial y anticipa la victoria escatológica del banquete del reino, y por simbolizarlas las hace presentes.

Toda la Escritura está escrita en una clave simbólica que desborda la mera lógica conceptual: Jesús es pan, cordero, pastor, puerta, vid, camino, vida, luz, alfa y omega, segundo Adán... El pueblo entiende este lenguaje, como comprendió a Jesús que hablaba en parábolas (Mc. 4, 33-34).

Digamos para concluir este apartado que la gran parábola del juicio final nos abre a una nueva dimensión del símbolo: Jesús se hace presente en sus hermanos más pobres (Mt. 25, 31-46): los pobres constituyen el símbolo privilegiado del Señor en la historia. Así como hay diferentes tiempos y momentos de salvación (Hech. 1,8 ), así también existen entre los mismos seres humanos símbolos privilegiados del Señor: los pobres son un símbolo particular de Jesús en medio de nosotros.

\section{Iglesia patrística}

La Iglesia primitiva y patrística es simbólica. Los padres mantienen una gran sintonía con el mundo bíblico y desarrollan una auténtica teología de la imagen (no solamente los padres alejandrinos). Sus reflexiones teológicas están llenas de símbolos. Así, la Iglesia es para los padres simultáneamente Eva y María, esposa y madre, casta y meretriz (Jos. 2, 1.21; 6, 17-25; Os. 2; Gn. 38; Jer. 50-51; Cant. 1,6...). La luna simboliza la Iglesia, ya que también la Iglesia brilla por la luz de Cristo, solo; desaparece ante el brillo del sol y con su fuerza dinamiza y fecunda el mundo. La imagen patrística más usada sobre la Iglesia es la nave, con alusiones tanto al arca de Noé (Gn. 6) como a la barca de Pedro (Mc. 4,38; Lc. 5,3s; Mt. 8,26; Jn. 21), que aunque fluctúa, no sucumbe. La polisemia de las imágenes permite una gran riqueza de significados y diferentes niveles de interpretación. ${ }^{2}$ Lo mismo ocurre con la exégesis patrística de la Escritura, la cual se desarrollará ampliamente en la primera edad media, sobre todo en la teología monástica.

Tal vez donde la patrística alcanzó su mayor capacidad de plasmación simbóljca fue en la estructuración del catecumenado. Las explicaciones cuaresmales a los catecúmenos que habían de ser "iluminados" en el bautismo, se concentraban en los ciclos del Génesis, del Exodo y del Jordán, donde se prefiguran simbólicamente diferentes tipos de bautismo cristiano. La solemne entrega (traditio) del Credo, símbolo apostólico, y su consiguiente devolución (redditio), eran ceremonias profundas simbólicas. Lo mismo sucedía con la traditio y redditio del Padre Nuestro, símbolo de la oración cristiana y de las actitudes del cristianismo ante Dios. Los exorcismos y, sobre todo, la definitiva renuncia a Satanás y a sus estructuras 
demoníacas, concretadas en el circo (pompa), alcanzaban gran solemnidad. Las ce. remonias de la misma liturgia bautismal en el escenario iniciático de la vigilia pas. cual, constitulan una verdadera dramatización simbólica: en el baptisterio que representa el seno materno de María y de la Iglesia, se desarrollaban una serie de gestos simbólicos: desvestición de las vestiduras del hombre viejo, inmersión en el agua, sepulcro y madre, unciones, revestimiento de las vestiduras blances de los recién nacidos a la vida nueva, entrada procesional a la basílica para participar ya de la eucaristía, mientras cantaban el Salmo 13 lleno de resonancias aacramentales:

El Señor es mi pastor,

a donde brota agua me conduce.

con aceites tú perfumas mi cabeza y rellenas mi copa.

No puede extrañarnos que muchos cristianos, bautizados de adultos, aunque fuesen de origen sencillo, gracias al catecumenado poseyeran una profunda teología. Este es el caso de muchos monjes, hombres rudos y sin letras, pero que gracias a esta penetración simbólica de los misterios de la fe, poseían lo que se ha lla. mado una auténtica Voklstheologie, seguramente muy superior a la que tienen muchos cristianos de hoy. Esta teología se iba alimentando a través de la Biblia y del ciclo litúrgico, verdadero catecismo popular a lo largo del año. Los pobres viven su fe al ritmo de las fiestas de la Iglesia.

La renovación patrística y litúrgica de la primera mitad del siglo $\mathrm{XX}$, la cual culmina en el Vaticano II, se basa en gran parte en las catequesis y homilías patrísticas dirigidas al pueblo sencillo de Constantinopla, Jerusalén, Roma, Milán o Hipone.

Pero en los padres hay otra dimensión bien evangélica de lo simbólico: el pobre no se puede desligar del sacramento del altar, la eucaristía comporta una práctica de justicia con el pobre, una comunicación de bienes. Es absurdo cubrir de riquezas el templo, mientras el pobre anda desnudo. ${ }^{3}$ Las ofrendas litúrgicas se destinan a los pobres y en la eucaristía pascual se mantenían a los esclavos.

Esta percepción de lo simbólico y esta sensibilidad hacia el pueblo sencillo llevará a la Iglesia patrística a asumir tradiciones y fiestas populares en el calendario cristiano y en la liturgia. Las fiestas de navidad y Juan Bautiota constituyen dos ejemplos clásicos de esta preocupación por trasplantar fiestas ancestrales del pueblo en el suelo de la Iglesia.

No se trata de idealizar el pasado de una Iglesia que también cometió errores y pecados, sino de reconocer que hubo un momento histórico en el cual la Iglesia y su teología fueron simbólicas y el pueblo pobre y sencillo se sintió integrado en la co. munidad eclesial de la que participaba activa y vitalmente. 


\section{Iglesia medieval}

La Iglesia medieval comenzó simbólica, no sólo en la tradición bizantina oriental, sino también en el occidente latino. Entre la teología patrística y la escolástica discurre la teología monástica de la alta edad media. Es una teologia sapiencial y contemplativa, lectio divina de la Escritura, en orden a la ruminatio y meditatio. Estrechamente ligada al monasterio, plasma su fe en las pinturas románicas y en la esculturas de los capiteles de sus claustros y de sus portadas monásticas, las cuales constituyen verdaderas catequesis populares. Es una teología en estrecha conexión con la espiritualidad y la liturgia, teología administrativa y afectiva (Credo ut experiar), que utiliza un lenguaje poético e imaginativo. La Biblia es penetrada en toda su profundidad, según la doctrina de los cuatro sentidos, típica de la exégesis medieval, profundamente estudiada por Henri de Lubac. La historia o letra de la Escrilura (vg. la Jerusalén judaica) conduce al sentido cristológico y eclesial de la alegoría (la Iglesia es la nueva Jerusalén), la cual se interioriza existencialmente en el sentido tropológico (cada cristiano es Jerusalén) y se distiende escatológicamente en el sentido anagógico (la nueva Jerusalén celeste). Aunque la teología monástica utiliza las artes liberales (trivium y quatrivium), la lectio prevalece sobre la dialectich, la collatio sobre la quaestio.

En este tiempo la Iglesia continúa teniendo conciencia de su dimensión comunitaria y simbólica del miaterio. La Iglesia es el verum corpus de Cristo, y la eucaristía es el corpus mysticum de Cristo.

Pero al filo del siglo XI, las perspectivas cambian. En expresión de H. de Lubac, la Iglesia pasó "del símbolo a la dialéctica."5

La reforma gregoriana, en su lucha por la libertas ecclesiae contra las intromiaiones del imperio, aceleró el paso de la Iglesia misterio de comuníon, típicamente patrística, a una Iglesia sociedad jurídica, concentrada en Roma y en el papa. La Iglesia romana es domina, mater y magistra y el papado lo centraliza todo, hasta hacer de la lglesia universal como la gran parroquia del papa. El sacerdocio es visto teológicamente como mediación pontifical entre Dios y los hombres, y su esencia es la potestas con relación a la eucaristía, la cual deade ahora es el corpus verum de Cristo, y sólo derivadamente hacia la Iglesia que ahora es el corpus mysticum. La doctrina del carácter aacramental es el principio teológico de esta potestad sacerdotal respecto a la eucaristía.

Surge una nueva teología, la escoléstica, ligada a las escuelas teológicas y a las universidades. La lectio divina cedió a la quaestio y a la disputatio. El aristotelismo se introdujo en el estudio teológico, la teología pasó a ser sobre todo una ciencia en el sentido aristotélico (cognitio vera ex causis), que aaca conclusiones de la Escritura en orden al intellectus fidei y a la fides quarens intelectum, y buaca ordenar y sintetizar los datos de la escritura, los padres y los maestros. La filosofía aristotélica introduce los nombres de materia y forma, esencia y existencia, acto y potencia, substancia y accidentes y las cuatro causas. La dimensión histórica de la salvación y de la vida de Cristo se subsumen en una visión orgánica y más filosófica, de la cual sólo grandes escolásticos, como Tomás de Aquino, se liberan. El símbolo se desdobla en signo y causa, los sacramentos son estudiados bajo las categorías de materia y forma, de modo que la riqueza simbólica de cada sacramento debe ceder a la 
organización unitaria del septenario sacramental. El mismo septenario sacramentaL, de esta época, nace como un deseo de sistematizar la analogía y multiplicidad simbólica de lo sacramental en la Iglesia.

Particularmente significativas de este paso del símbolo a la dialéctica son las controversias eucarísticas del siglo IX (Pascasio Radverto y Ratramno de Corbie) y del siglo XI (Berengario de Tours). Ya no se sabe cómo conciliar lo simbólico con lo real: o bien se defiende la identidad de Cristo histórico y el Cristo eucarístico con un realismo no simbólico (Pascasio Radberlo), o bien se afirma la dimensión simbólica de la eucaristía (Ratramno y Berengario), pero con una mentalidad que considera que lo simbólico no es real ni histórico, sino meramente místico y espiritual (figura, semejanza, imagen). Es el triunfo de la dialéctica sobre el símbolo, del realismo científico y posilivista sobre la verdad bíblica y patrística. El mismo magisterio, para preservar la realidad de la presencia eucarística, tiene que decir que ésta no es meramente simbólica o mística. Desde esta época, como hemos insinuado, "el verdadero cuerpo de Cristo" será la eucaristía, mientras que la Iglesia será el "cuerpo místico de Cristo," invirtiendo así la perspectiva patrística y de la primera edad media. $^{6}$

Estos profundos cambios teológicos tendrán graves repercusiones en la vida de la Iglesia. No es casual que la separación de las iglesias de oriente se produzca a comienzos del siglo XI (1054) y que se inicie en esta época el divorcio entre espiritualidad y teología, el cual se consumará hacia el siglo XIV, y sobre todo comience la trá. gica división entre la Iglesia oficial y el pueblo. En concreto, se rompe la unidad entre el sacramento del altar y el sacramento del hermano, especialmente el pobre.

El pueblo se siente cada vez más alejado de una Iglesia centrada en la autoridad y el poder, de una teología cientílica, pero poco popular y de una liturgia ininteligible. El intento de alegorizar la liturgia eucarística no convence al pueblo, que posee un sentido a la vez simbólico y realista. El mundo simbólico se refugia en la religiosidad popular y en algunns sectores de la mística (que para expresar sus experiencias inefables acude a los símbolos de la llame, la herida, las moradas, la noche oscura, los desposorios, el nacimiento interno del Verbo, la centella...).

Los movimientos comunitarios, laicales y populares, que surgen precisamente en estos siglos, tienen un claro carácter de contestacion y de insatisfacción ante una liturgia incomprensible y una Iglesia clerical y autorilaria. El pueblo necesita otro tipo de vida cristiana, más encarnedo y simbólico al mismo tiempo. La devoción a María, a la humanidad de Jesús, a los santos, responde a esta inquietud. Surge la devoción popular a María, nacen nuevas oraciones marianas populares (Ave María, Angelus, Salve, Stabat Mater, el rosario que es el salterio del pueblo), las imágenes de María recobran mayor dulzura y realismo (María con el Niño, la Piedad...), aparecen leyendas marianas que celebran la misericordia y el poder de María, cobran importancia los santuarios marianos los cuales se convierten en lugarea de peregrinación popular. María simboliza la misericordia de Dios, en un mundo donde prevalece la imagen de un Dios justiciero y de una Iglesia inquisitorial. El mundo de los pobres halla en María el símbolo de la protección, del relugio y de la seguridad, en una sociedad marcada por la pobreza, Ia incertidumbre, el horror al demonio y el miedo al más allá. La devoción a la humanidad de Jesús, a su nombre y a los "misterios de la vida de Cristo," se concretan en 
representaciones dramáticas de "misterios" y luego de autos sacramentales en los atrios de las catedrales. Surge así una liturgia "del atrio" que rivaliza con la del templo. Francisco de Asís representa en Grecchio el nacimiento de Jesús en el pesabre, ${ }^{7}$ y el vía crucis se convierte en una devoción popular para el tiempo de la cuaresma. Los sanlos y sus reliquias son venerados, y las fiestas patronales de los gremios, las peregrinaciones y romerías alcanzan gran popularidad. Así vive el pueblo su fe.

Evidentemente no siempre es posible separar en estos movimientos populares lo auténticamente evangélico de lo espúreo. Bajo el grito de "vuelta al evangelio," a veces se entremezclan peligrosos riesgos de herejías milenaristas, de catariamo dualistas y de posturas poco eclesiales. Pero es innegable que estos movimientos representan una clara afirmación del mundo simbólico, postergado en la teología oficial.

\section{Iglesia moderna}

La pérdida de los simbólico en la teología persiste y se profundiza en la Iglesia de la época moderna. La contrarreforma teme afirmar el símbolo para no ceder a la reforma, la cual reacciona contra el realismo sacramental medieval con un simbolismo que ya no es manifestación de lo real. La escolástica y la neoescolástica de los siglos posteriores mantienen las categorías aristótelicas del siglo XII, muchas veces sin las correcciones de los grandes teólogos medievales. El espíritu de la ilustración ticnde a recalcar las dimensiones más lógicas y moralizantes de la revelación. Es cierto que el romanticismo es más generoso con el símbolo y el misterio (por ejemplo, K.A. Mohler con su Symbolik, y la escuele de Tubingen), pero en realidad prevalece una visión racional y autoritaria tanto de la fe como de la Iglesia. Su expresión eclesial más clara es el Vaticano I con las constituciones dogmáticas $D e i$ Filius sobre la fe y Pastor Aeternus sobre la Iglesia.

El Vaticano II, también en este terreno, representa una vuelta a la tradición bíblica y patrística más primitiva, recogiendo lo mejor de los movimientos bíblicos, litúrgico y patrístico. Las constituciones dogmáticas sobre la Iglesia, la liturgia y la revelación, son generosas con el símbolo. El hecho de definir a la Iglesia como aacramento ( $L G ~ 1 ; 9 ; 48$ ) es un paso decisivo en la recuperación del símbolo. Sin embargo, la descripción del sacramento como "signo e instrumento" (LG l) indica que todavía persisten categorías escolásticas en la noción del símbolo y que falta todavía una visión más integral. El camino está solamente iniciado.

Por olra parte, la teología de post-concilio ha desarrollado, en el primer mundo sobre todo, las dimensiones científicas y seculares de la [e. No deja de ser sintomático que el mismo Pablo VI, tan amigo de gestos simbólicos como renunciar a bu tiara papal, en su encíclica Mysterium fidei para responder a ciertas teologías holandesas en torno a la eucaristía, contraponga nuevamente la presencia real de Cristo en la eucaristía a la simbólica... En estos últimos años, por el contrario, como hemos visto, asistimos a una loma de conciencia teológica de la importancia del símbolo. ${ }^{\mathrm{B}}$

Este breve recorrido histórico sería incompleto sin no aludimos a la Iglesia latinoamericana. La evangelización se inicia bajo la égida de la Iglesia medieval hispá- 
nica, pero pronto vivirá el eco de las controversias de la reforma y de la reacción católica de la contrarreforma. Hay que reconocer, como afirma Puebla, que la obra evangelizadora en América Latina realizó un gran esfuerzo y cuenta en su haber con notables eintesis de evangelización y promoción humena y con une gran inventiva en la pedagogia de la fe: "la vasta gama de recursos que conjugaban todas las artes. desde la música, el canto y la danza, hasta la erquitectura, la pintura y el teatro" (Puebla 9). Sin embargo, este notable esfuerzo pastoral no siempre estuvo acompa. ñado y dirigido por una visión coherente del símbolo, ya que América Latina dependía teológicamente de la escolástica europea y de la apologética antiprotestante. Las conferencias de Medellín y Puebla, posteriores al Vaticano II, abrieron para América Latina un camino luminoso de mayor integración de lo simbólico en la vida ecleaial, litúrgica y en la religiosidad popular (Puebla 444-469; 895-963), orientándolo todo en una perspectiva liberadora. Por ejemplo, en Puebla (940) se habla de "revalorizar la fuerza de los 'signos' y su teología." Y todo ello teniendo presen. te que en los rostros de los pobres (niños, jóvenes, indígenas, campesinos, obreros, subempleados, marginados, ancianos...), se hallan presentes los rasgos sufrientes de Cristo el Sefior (Puebla 31), llegando de este modo a una opción preferencial por los pobres (Puebla 1134-1165). Este es precigamente el marco de nuestra actual reflexión sobre el símbolo.

\section{Algunas consecuencias de la pérdida de lo simbólico en la teología}

La pérdida u olvido del símbolo ha traído consecuencias negativas tanto para la teología como para el mismo pueblo. Sin ánimo de agotar el tema, enumeremos algunos de los caṕ́tulos més significativos de esta paulatina depauperación simbólice.

\section{Relatos de orígenes}

Los relatos de los once primeros capítulos del Génesis, y en concrelo el tema del paraiso, al ser interpretados desde una mentalidad histórica informativa y científica, han creado una serie de dificultades y de pseudoproblemas insolubles.

Al olvidar que forman parte de un género literario mítico y simbólico, se ha incurrido en preguntas tan absurdas como ¿dónde estaba el paraíso? ¿La primera pareja humana ae llamaba realmente Adán y Eva? ¿Es verdad que Eva fue formada de la costilla de Adán? ¿Dios hizo de alfarero y de enestesista? ¿Hablaban antes las ser. pientes? ¿Cuál fue la fruta prohibida?... La pérdida de la mentalidad simbólica creó problemas entre la fe y la ciencia y sobre la posibilidad para un cristiano de admitir el evolucionismo, el poligenismo o el parto sin dolor. El dogma del pecado original provocó en muchos lectores dificultades insuperables por no percibir el sentido corporativo del personaje Adán, símbolo de la humanidad pecadora que somos cada uno de nosotros, y cabeza de una humanidad que en Cristo, Segundo Adán, será renovada y salvada (1Cor. 15,45). Afirmaciones sobre estos primeros capítulos del Génesis por parte de la comisión bíblica (ctr. DS 3512-3519; 3862-3864; 3898) y de la encíclica Humani generis revelan también una no adecuada comprensión de lo sim. bólico en la teología b́blica de aquellos años anteriores al Vaticano II. 
Las consecuencias de todo ello han sido graves: un cierto desprestigio de la fe ante la ciencia, un vano intento de concordismo, crisis de conciencia de muchos cristianos ilustrados, desconcierto del pueblo, etc. Más aún, la nostalgia del paraíso ha actuado como freno desmovilizador para el pueblo y como excusa para la resignación pasiva, cuando una lectura simbólica del mismo, debería ver en el paraíso una profecía del futuro, proyectada en el pasado.

Los relatos fundacionales de la Iglesia, al ser leídos de forma no simbólica, crean también dificultades y malentendidos. Una visión juridicista e institucionalista lee, por ejemplo, Mateo 16 como la creación de una sociedad religiosa, dotada de leyes, autoridades y medios para subsistir a lo largo del tiempo, olvidando que aunque la Iglesia tiene su fundamento en el Jesús histórico pre-pascual y en la comunidad por él formada, no nace propiamente sino después de la ruptura de la cruz y del evento de pascue-pentecostés. Las discusiones modernas acerca de la fundación de la Iglesia, cuando olvidan el caránter simbólica de los relatos fundacionales, o caen en un institucionalismo juridicista y fundementalista, o desembocan en las posturas modernistas de un Loisy. Solo de forma simbólica se puede hablar del acontecimiento cristológico y pragmático de la Iglesia, verdadero misterio de salvación en nuestra historia. Los padres de la Iglesia eran mucho más profundos y respetuosos ante este misterio al verlo prefigurado simbólicamente en la sangre y en el agua derramados por Cristo traspasado (Jn. 19,34), agua bautismal y sangre eucarística, que constituye los fundamentos sacramentales de la Iglesia, nueva Eva nacida del costado del nuevo Adán dormido y exaltado en el árbol de la cruz. La polisemia de los símbolos, que desconcierta a los espíritus cartesianos y escolásticos, es fácilmente comprendida por el pueblo sencillo. También los relatos de los orígenes eclesiales tienen mucho de profecía y de eclesiogénesis pneumática, de una Iglesia que el Espíritu rejuvenece y renueva constantemente hasta conducirla a la unión consumada con su esposo (LG 4). Cuando esto se olvida, la eclesiología degenera en arqueología de museo.

\section{Vida cristiana}

Al perderse el sentido simbólico, la Iglesia se llega a definir como "sociedad perfecta," tan visible e histórica como "la república de Venecia" (Bellarmino). Los mismos símbolos eclesiales, interpretados de forma puramente lógica, conducen a conclusiones desorbitadas. Así la imagen de la nave o del arca, cuando se extrapola, conduce al rigorismo del extra ecclesiam nulla salus, cuyo representante último fue L. Feeney (DS 3866-3873). La misma imagen del cuerpo de Cristo, si se interpreta unilateralmente y de forma jurídica, lleva a perderse en disputas sobre la pertenencia a la Iglesia (quaestio de membris)y a identificar el cuerpo místico de Cristo con la Iglesia romana. No se puede criticar el privilegiar un símbolo (por ejemplo, el $\mathrm{V}_{\mathrm{a}}$ ticano II en Lumen gentium; privilegió sin duda el de Pueblo de Dios), pero no es lícito absolutizarlos (por ejemplo, afirmando que sólo es legítimo el de cuerpo de Cristo). No se puede contraponer el símbolo de la Iglesia madre al de Iglesia esposa, sino se quiere caer en una jerarcología parcial. $\mathrm{Ni}$ al contrario. La Iglesia es un mislerio y cuando se prescinde de su expresión simbólica se la convierte en una simple institución. 
La lectura no simbólica del ministerio petrino, iniciada sobre todo a partir de Gregorio VII, ha tenido consecuencias serias para la eclesiología y para la vida cristiana. Los símbolos de roca, llaves y pastor, indican ser signo de unidad y de comunión, de autoridad para el servicio, palabra eutorizada para confirmar la fe de los hermanos y salvaguardar la comunión eclesial, apacentando el rebaño confiado, sobre todo con el propio testimonio de vida (1 Pe. 5,3). La Iglesia local de Roma, por sus origenes santificados por la sangre martirial de Pedro y de Pablo, posee una primacía entre todas las iglesias locales y se constituye en el lugar simbólico de esta "presidencia en la caridad" (Ignacio de Antioquía) de los sucesores de Pedro. El obispo de Roma posee el carisma y la misión petrina y es el símbolo de la comunión eclesial (koinonia).

Pero al perderse lentamente esta sensibilidad simbólica, Roma se convierte en fuente, origen de toda la Iglesia, el papa llega a ser "obispo universal" y sus mismas denominaciones evolucionan: de vicario de Pedro (Lén Magno) pasa a llamarse vicario de Cristo (Juan VIII) y vicario de Dios (Inocencio III). La eclesiología de comunión se transforma en eclesiología jurídica, de autoridad y de poder centralizado, y los tratados de eclesiología se convierten en tratados sobre el poder pontificio.

Las consecuencias de este proceso han sido trágicas: separación de las iglesias de oriente y de las de la reforma, y el hecho de que el papado, que debería ser símbolo de la unidad y de la comunión, constituye actualmente "el obstáculo más grave en el camino de ecumenismo." $\mathrm{El}$ pueblo sencillo, sin perder "el afecto cálido por la persona del Santo Padre" (Puebla 454), como lo demuestran los viajes pontificios, no deja de mirar al Vaticano como un poder, semejante a los poderes de este mundo. ${ }^{10}$

La pérdida del sentido simbólico ha afectado de modo peculiar a los sacramentos. De símbolos eclesiales pasan a ser instrumentos eficaces de la gracia, causas instrumentales sobre las cuales las escuelas teológicas disputarán sobre su tipo de causalidad (moral, física, jurídica...). La institución de los sacramentos por Cristo, leída desde una visión juridicista de la fundación de la Iglesia, se agota en la teología clásica medieval en consideración sobre el vínculo inmediato entre los sacramentos y la voluntad implícita o explícita de Cristo, olvidando las dimensiones eclesiológicas pneumáticas y simbólicas del tema. Los sacramentos se vinculan directamente a la encarnación de la cual son prolongación, pero sin pasar por la lglesia, ni por el misterio de pascua-pentecostés. Se llega así a una visión objetivista, minimalista y extrinsecista de los sacramentos, canales de gracia que producen la salvación cuando no se pone óbice. Las dimensiones significativas y simbólicas han quedado opacadas y la misma liturgia sacramental se empobrece: el agua bautismal, por ejemplo, se reduce a la infusión de unas pocas gotas y su sentido se limita al de lavar. El sacerdote es un mediador, un administrador, un hombre de sacramento, más que el responsable de la comunidad eclesial, quien al presidir las celebraciones, sobre todo la eucaristía, simboliza la referencia absoluta de la Iglesia a Cristo. ${ }^{11}$

En algunos sacramentos esta pérdida de lo simbólico ha llevado a problemas intrincados. El caso más típico sería el matrimonio. El misterio del amor de Cristo a su Iglesia, simbolizado sacramentalmente por la mutua entrega amorosa de los esposos cristianos, parece desvanecerse cuando tiene la primacía la dimensión de contrato jurídico, rato y consumado, reddere debitum, y su finalidad se divide en un 
fin primario (la procreación de la prole) y un fin secundario (la ayuda mutua y el remedio de la concupiscencia). Muchos problemas teológicos, morales, incluso canónicos del matrimonio (divorcio, indisolubilidad, consumación, moral lamiliar, regula. ción de la natalidad...) sólo podrán tener una adecuada solución cuando se le devuelva al matrimonio su dimensión verdaderamente simbólica. La Iglesia oriental, que ha mantenido la tradición simbólica del matrimonio, posee una teología y una moral rica de este sacramento.

También la vida religiosa, que no es sacramento, ha quedado perjudicada al ser considerada de forma no simbólica. La vida religiosa en sus orígenes mantuvo un claro sentido de símbolo profético y escatológico del reino, testimonio martirial del seguimiento de Jesús y de la tensión hacia la utopía. En la edad media pasó a ser instituto de perfección, estado de perfección, del cual los tres votos constituyen su garantía jurídica. No es casual que la tríada de pobreza, castidad y obediencia, así formulada sea del siglo XII. De este modo, el pueblo de Dios se divide, en la práctica, en los seguidores de los mandamientos (el pueblo) y los cultivadores de los conse. jos evangélicos (los religiosos). La vida religiosa adquiere un rango de estado aristocrático en la Iglesia, el cual le permite dispensarse de examinar su sentido profético en la Iglesia y en la sociedad.

\section{Escatología}

La escatología cristiana también se ha empobrecido al convertir el rico arsenal simbólico del apocalipsis y de la parusía en el moralismo de los novísimos y en consideraciones abstractas e individualistas sobre la visión bealífica. No es casual la simultaneidad entre la pérdida del símbolo, la disminución eclesial de la tensión escatológica y la instalación de la Iglesia en este mundo, confundiendo la encarnación con la mundanización y la legitimación del sıatu quo. La Iglesia sin escatología se convierte en institución de poder e ideología de vencedores. Al revés, la escatología ayuda a mantener viva la distancia entre el "ya si" y el "todavía no," entre "este mundo" y el reinado definitivo de Dios. Precisamente cuando la Iglesia institucional apaga las imágenes de la escatología del reino, el pueblo busca a través de movimientos utópicos y milenaristas, una compensación a los dolores de esta vida y al déficit de esperanza simbólica eclesial. Joaquín de Fiore es del siglo XII.

El género apocalíptico encuentra gran resonancia en los sectores marginados de la sociedad, los cuales ven en la parusía y en los símbolos de la nueva Jerusalén una respuesta a sus inquietudes, ya que en la parusía queda claro que el reino es para los pobres y quienes sulren persecución, que Dios "derriba del solio a los poderosos y exalta a los humildes" (Lc. 1,52). Los "sin futuro histórico" son los más sensibles al anuncio de la parusía, y buscan en los símbolos apocalípticos una alternativa a este mundo injusto. Sólo una Iglesia de los pobres, puede mantener viva la esperanza del reino de Dios y la crítica a los dioses de este mundo. Los símbolos apocalípticos subvierten el orden establecido. La Iglesia, al olvidarlos, se hace incapaz de decir una palabra de esperanza al pueblo pobre y se identifica en la práclica con los intereses de los señores de este mundo. Una Iglesia sin símbolos escatológicos deja de ser profética. El pueblo necesita que le anuncien que Babilonia caerá y que la mujer coronada de doce estrellas vencerá al dragón. ${ }^{12}$ 


\section{El pueblo perdedor}

La víctima primera de todo este olvido de lo simbólico es el pueblo sencillo y pobre. Sin orígenes y sin escatología simbólica, marginado de una Iglesia cada día més convertida en institución de poder, alejado de los sacramentos eclesiales para los cuales se le exigen unos requisitos intelectuales que superan con frecuencia sus posibilidades reales, alejado de la perfección que parece destinada a los religiosos... el mundo de los pobrea deja de ser el sujeto privilegiado de la evangelización y del reino, para ocupar un lugar periférico no sólo en la sociedad, sino en la misma Igle. sia y en la teología. El pobre no aparece como un símbolo de Cristo (Mt. 25), sino co. mo una pesada carga y un simple objeto de beneficiencia eclesiástica. La Iglesia parece identificarae con el mundo de la riqueza, del poder y de la racionalidad ilustra. da.

Afortunadamente el Vaticano Il ha supuesto une revisión de toda esta situación. Se inicia un redescubrimiento de lo simbólico en la escritura (DV), la Iglesia (LG, AG, GS), los sacramentos (SC), en la vida religiosa (LV VI y PC) y en la escatología (LG VII). Consiguientemente se vuelve al ideal de una Iglesia de los pobres, preconizado por Juan XXIII.

\section{V. ¿Cómo potenciar lo simbólico en la teología?}

Es siempre más facil detectar los errores que hablar de caminos alternativos. Con todo, proponemos algunas pistas posibles para esta potenciación de lo simbólico en la teología.

\section{Recuperar el símbolo cósmico}

El primer paso para la recuperación de lo simbólico en la teología estriba en recuperar la dimensión cósmica de la fe. Ciertamente las grandes hazañas de Dios se inscriben en la historia salutis, pero esto no implica una desmaterialización de la dimensión cósmica de la salvación. La historia de la salvación, desde el Génesis al Apocalipsis, se inscribe en un escenario de materia creada por Dios, tierra y cielos que deberán irse transfigurando hasta constituir los cielos nuevos y la nueva tierra de la escatología. Es preciso reelaborar una teología de la creación, que no se limite a desarrollar unilateralmente el mandato de dominar la tierra y someterla (GN 1,28), sino que sepa contemplar la creación como un símbolo de Dios. ${ }^{13}$

Los cielos y la tierra, los frutos de la tierra, el agua, el pan, el vino, el aceite, sobre todo el cuerpo humano, son símbolos misteriosos de realidades trascendentes. Ś́lo a partir de aquí es posible revalorizar el sentido del símbolo. Las teologías que desmaterializan la salvación son incapaces de comprender la encarnación, María, la Iglesia y los sacramentos. Propensas a esta incomprensión dualista son no sólo las teologías de la reforma, sino también algunas corrientes católicas. Se ha observado que Aguslín, por su pasado de pecado, no logró nunca reconciliarse con el cuerpo, ni con la materia. 
Al revés, el mundo de la religiosidad popular, muy ligado a lo rural, es muy sensible a lo cósmico y a su analogía simbólica. La tierra es a la vez madre fecunda que nos alimenta, Virgen María, lugar de reposo sepulcral y seno de una nueva vida. La Pachamama andina recoge todos estos significados que turban a los espíritus demasiado lógicos y unívocos. El mundo del oriente cristiano y su teología de la trans「iguración pueden aportarnos mucho a esta recuperación teológica del sentido de la tierra y de la materia y a su capacidad simbólica. ${ }^{14} \mathrm{El}$ desarrollo moderno de las ciencias ecológicas concuerda con este respeto profundo al sacramento de la creación cósmica, el cual resiste a ser considerado solamente como objeto de explota. ción, depredación y consumo.

Esta recuperación cósmica permitirá una relectura positiva de los relatos de orígenes y de la escatología, orientando la vida no hacia una nostalgia del paraj́so, sino hacia la búsqueda de la tierra nueva. Y todo ello desde la perspectiva de los pobres, quienes son los únicos que pueden llegar a comprender lo que significa caminar hacia la ulopía del reino. Sólo una Iglesia de los pobres puede mantener encendidos los símbolos de la esperanza del reino y clamar ¡Ven Señor! La Iglesia de América Latina, que vive teológicamente en tiempo de adviento, necesita reavivar esta esperanza. Los escritos de Carlos Mesters son un modelo de esta recuperación simbólica de los orígenes y de la escatología. ${ }^{15}$

Desde esta perspectiva es posible revalorizar las dimensiones simbólicas de la liturgia cristiana y de la liturgia de la vida: sacramentos y sacramentales, celebraciones festivas, imágenes e iconos, cantos y danzas populares, ofrendas y toda la rica simbólica de la religiosidad popular.

Indudablemente toda materia debe ser iluminada y purificada desde el miste. rio de la cruz y la resurrección de Jesús, pero una profundización del sentido teológico del cosmos nos ofrece una postura de simpatía inicial al símbolo, sobre todo a los de la religiosidad popular, que es la religión de los pobres (EN 48). Una auténtica pastoral liberadora ha de ser simbólica, comenzando por los símbolos cósmicos.

\section{Redescubrimiento del simbolismo histórico}

No basta potenciar los símbolos cósmicos, hay que redescubrir los símbolos históricos. El talante católico del simbolismo cósmico debe complelarse, según Tillich, con el talante protestante de lo utópico. Asistimos hoy a un desplazamiento de lo sagrado hacia el polo profético e histórico. La historia sigue constituyendo la mediación privilegiada de la salvación, ${ }^{16}$ el lugar donde se manifiesta simbólicamente la gracia del Señor. Esta historia no es homogénea, sino que en ella hay momentos de especial densidad salvífica, de incandescencia escatológica, tiempo de gracia y de visita de Dios, tiempos oportunos, Kairós en lenguaje bíblico (2Cor. 6,2). El Vaticano II desarrolló la teología de los signos de los tiempos (GS 4, 11, 44), de raíces bíblicas (cfr. Mt. 16,3).

Pero hay que concretar más esla perspectiva desde América Latina, siguiendo a Medellín y a Puebla, el gran signo de nuestro tiempo es el ansia de liberación de los pueblos pobres y oprimidos, cuyo clamor sube al cielo de forma clara, creciente, impetuosa y amenazante (Medellín, "Pobreza de la Iglesia" 2; Puebla 87-89). El cla- 
mor de los pobres es hoy el símbolo hislórico prototípico de la salvación en América Latina. 17

Este clamor de los oprimidos, como todo símbolo verdadero, posee una clara ambivalencia: es símbolo de muerte y de vida. El clamor de los pobres es símbolo de muerte en la medida en que expresa el sufrimiento injusto del pueblo, su dolor, el pecado de una sociedad estructurada injustamente, demoníaca, dominada por los dioses de la muerte, por la bestia apocalíptica. Este clamor se manifiesta en América Latina a través de las formas más variadas: manifestaciones de mujeres con cacerolas vacías, canciones de protesta, marchas de las madres argentinas de la Plaza de Mayo y de las madres salvadoreñas ante catedral, quienes reclaman a sus hijos desaparecidos, huelgas de metalúrgicos brasileros, huelgas de hambre de mineros bolivianos, concentraciones contra las dictaduras militares, contra el FMI y los países del norte...

Este clamor del pueblo es el clamor del Siervo de Yahvé, el clamor del crucificado. Saber escuchar este clamor, discenirlo, sentirse interpelado por él, es tarea teológica ineludible hoy en todo el mundo y concretamente en América Latina.

La reciente Oda a Reagan, del obispo Pedro Casaldáliga puede ser un ejemplo de este clamor de denuncia y de la dimensión simbólica y profética de este grito del pueblo.

Te excomulgan conmigo los poetas, los niños, los pobres de la tierra.

¡Oyenos

Hay que pensar humanamente el mundo!

No te hagas el Nerón.

La raza de los hombres ya no está para imperios.

Reagan, escucha: el sol

nace sol para todos

y llueve el mismo Dios

sobre todas las vidas que ha llamado a la fiesta.

Ningún pueblo es mayor.

Haz el patio en tu casa,

¡Respétanos!

Raquel te sabe Herodes,

y habrás de responder por su desolación.

Podéis creeros dueños, podéis tenerlo todo, incluso dios, jtu dios!,

-el ídolo sangriento de tus dólares

el maquinal Moloch-

pero te Calta el Dios de Jesucristo,

la Humanidad de Dios.

Yo juro por la sangre de Su Hijo,

que otro imperio mató,

y juro por la sangre de América Latina

- preñada de auroras hoy-

que tú 


\author{
serás el último \\ (grotesto) \\ emperador. 18
}

Pero el clamor es también símbolo de vida, simboliza el ansia de liberación de los pueblos oprimidos, la fe en el Dios de la vida, la esperanza de un mundo mejor, la a firmación de la utopía del reino desde su negatividad pecaminosa, la anticipa. ción de la tierra nueva, la alegría en medio de los dolores del parto del nacimiento de una nueva humanidad. Es la sangre de los Romero, Espinal, Joao Bosco Penido Burnier, Angelleli, de mujeres desconocidas, de catequistas, de niños, de religiosas, que claman justicia y cantan el cántico victorioso de quienes han sido blanqueados con la sangre del cordero (Apoc. 7,14).

Es el clamor de la nueva vida que surge por doquier: comunidades eclesiales de base, nuevos ministerios, nueva imagen de sacerdotes y de obispos, vida religiosa inserla entre los más pobres... Son los indios Tapirapé quienes ante la cercanía evangélica de las hermanitas de Jesús, vencen su desesperación y deciden oplar nuevamente por la vida y procrear hijos. Es la Misa Nicaragüense que canta al Dios de los pobres. Es la alegría del pueblo ante todo avance de libertad, fraternidad y humanidad. Es la fiesta cuando un país pasa de la dictadura militar a la democracia, o cuando se hace justicia a los antiguos opresores del pueblo. Son las fiestas populares - carnaval, fiestas patronales- que constituyen un grito de esperanza en medio de una situación de muerte y realizan las bienaventuranza de la risa de los pobres. Son las nuevas versiones del Magníficat de las mujeres nicaragüenses que cantan al Dios liberador. Es la nueva poesía y la nueva narrativa de América Latina que sorprende al mundo por su creatividad y su vitalidad, cuando parecería que sólo puede narrar la triste "crónica de una muerte anunciada" por todos los grandes de este mundo y los poderosos países del norte...

Una teología que desee ser simbólica y popular deberá saber discernir en estos gritos de vida el clamor del Espíritu que gime por su liberación.

\title{
VI. Conclusión
}

Nuestro punlo de partida para reflexionar sobre el símbolo ha sido la opción por los pobres. Desde el pobre, como símbolo privilegiado de Jesús y desde su culıura y religiosidad profundamente simbólica, se esclarece con una nueva luz la dimensión simbólica de la teología.

Ahora, al concluir estas reflexiones llegamos a la conclusión de que la misma opción preferencial por los pobres es una opción simbólica de una Iglesia que desea ser Iglesia de todos, pero en especial de los pobres. Es sintomático que quienes se mueven dentro de los esquemas más racionales y menos simbólicos de la teología moderna interpreten la opción por los pobres como exclusivismo y se escandalicen de esta parcialidad eclesial que creen lesiona la universalidad católica. Incluso intentan aguar esta expresión hasta vaciarla de contenido. La opción por los pobres sería una hermosa frase, nada más.

La opción por los pobres es un gesto simbólico y profético como los realizados por los profetas del Antiguo Testamento y, por el mismo Jesús, quien al privilegiar 
el sector popular expresa simbólicamente el amor misericordioso de Dios para con los que sufren injustamente, más allé de toda consideración moral o personal sobre la conducta de los mismos pobres (cfr. Puebla 1142). Ea la forma simbólica de expresar hoy que Dios es Dios de la vida, de la justicia y el derecho, de la gracia y la misericordia. Sólo desde una mentalidad simbólica se puede comprender que la opción por los pobres, lejos de herir la universalidad, es la única forma concreta de realizarla hoy.

Nos hallamos ante un "círculo simbólico-popular:" sólo desde la opcí́n por los pobres se puede llegar a comprender el simbolismo cristiano y sólo desde el simbolismo se puede comprender la opción de la Iglesia por los pobres. Círculo no vicioso, sino salvador y liberador, que exige de todos una mayor inserción en la historia de dolor de los pobres.

Este es el aporte de los países pobres al universo teológico del símbolo: no hay auténtica simbología, ni en el dogma, ni en la liturgia, si se margina a los pobres.

Podríamos resumir todo lo dicho de forma simbólica, recordando, con Puebla, que la identidad histórica, cultural y evangélica de América Latina "se simboliza muy luminosamente en el rostro mestizo de María de Guadalupe, que se yergue al inicio de la evangelización" (Puebla 446).

Pero este rostro mestizo de María, "gran signo de rostro maternal y misericordioso de la cercanía del Padre y de Cristo" (Puebla 282), se inclina precisamente hacia el indio Juan Diego, el más pequeño de sus hijos, simbolizando de eate modo au opción preferencial por los pobres. Las vírgenes de América Latina - Guadalupe, Copacabana, Aparecida, Luján... encarnan simbólicamente la auténtica tradición. Por eso el pueblo las siente cercanas y las venera con devoción filial. María ejemplifica de Corma luminosa toda la densidad y gravidez teológica del símbolo: ella nos comunica a Jesús, misterio de liberación. María es el prototipo de una teología simbólica y popular.

\section{NOTAS}

1. K. Rehner, "Para una leología del simbolo," Escritos de teologia, IV, Madrid, 1961, 283-321, con bibliografle.

2. H. Rahner, Symbole der Kirehe, Die Ekklesiologie der Vdter, Salzburg, 1964.

3. Juan Crisóstomo, In Mt, hom 50,4: PG 58, 509-510.

4. L. Maldonado, Religiosidad popular, Madrid, 1975, 321-360.

5. H. de Lubar, "Corpus Misticum, L'Eucharistic et l'Eglise au moyen age," Períb, 1949, $248-277$.

6. E. Vilenova, Historia de la teología cristiane Vol 1, Barcelona, 1984, especielmente 377 so.

7. "Si deseas que celebremos en Grecchio la prórima liesta del Natalicio divino, adelántate y prepara con diligencia lo que voy a indicarte. Para hacer memoria con mayor naturalidad de aquel divino niño y de las incomodidades que sufrió al ser reclinado en un pesebre y puesto sobre húmeda paja junlo a un buey y a un asno, quisiera hacerme de ello cargo de manere palpable y como si lo preaen. ciara ron mia propios ojos." T. de Celano, Vida de San Franciseo, Libro I, cap. XXX, n. 84.

8. V. Codina, "Tcología dionisíaca," en Teología y experiencia espiritual, Santander, 1977, 243-270.

9. Pablo Vl, carta del 28 de abril de 1967 al Secrelariado para la Unidad de los Cristianoa.

10. J.M.R. Tillard, L'éveque de Rome, Paris, 1982. Y.M. Congar, "Títulos dados al papa," Concilium, 1975, 108, 194-206.

11. L. M. Chauvet, Du symbolique an symbole, Parla, 1979, 131.141; 244246.

12. R. Aguirre, Reino, parusia, decepeión Madrid, 1984. 
13. A. Gesché, "La crétion: cosmologie el anthropologie," " Revue Théologique de Louvain, 1983, 14, 147-166, resumido en Selecciones de Teologia, 1985, 95,163-170 con el tifulo "¿Recuperar una teologfo de la creación?""

14. V. Codina, "Teología de la liberación y teología oriental. Una aproximación," Revisla Latinoame. ricana de Teología. 1985, 5, pp. 147-170.

15. C. Mesters, Paraiso ierresire, saudade ou esperanca? Peírópolig, 1983. 6 Abraho e Sarn, Petrópolis 1984. Esperanca de un povo que lus $O$ Apocalipse de Sao Joño, Sao Pablo, 1989.

16. I. Ellacuría, Conversión de la Iglesia, al Rejino, Santander, 1984, 219-263.

17. J. Comblin, $O$ clamor dos oprimidos, o clamor de Jesús, Petropolig, 1984. V. Codina. "Teologfa del clamor popular," Revista Latinoamericana de Teologia, 1984, 3, 309.328.

18. P. Casaldáliga. "Oda a Reagan," Amanecer (Managua) 1985, 36-37, pp. 44. 
Digitalizado por Biblioteca "P. Florentino Idoate, S.J." Universidad Centroamericana José Simeón Cañas 